\title{
Det komplicerade kvinnoblivandet
}

\author{
Jakobsson, Hilda. 2018. Jag var kvinna: Flickor, kärlek och sexualitet \\ i Agnes von Krusenstjernas tidiga romaner. Avhandling. Stockholm: \\ Makadam. (289 sidor)
}

"JAG KÄNDE MED ens, hur jag växte, blommade. Jag var kvinna, och jag hade icke vetat det. Darrande foro mina händer över min kropp. Kvinna!” (Krusenstjerna 1924, 26r) Obestridligt Agnes von Krusenstjerna (I894-I940). Hennes unga huvudperson i romansviten om Tony (I922I926) kommer till insikt om sin kvinnoidentitet när hon börjar älska. Hur processen gestaltas litterärt utreder Hilda Jakobsson omsorgsfullt i sin doktorsavhandling Jag var kvinna: Flickor, kärlek och sexualitet i Agnes von Krusenstjernas tidiga romaner, framlagd vid Stockholms universitet i december 2018 .

Det är den fjärde doktorsavhandlingen som helt ägnas åt Agnes von Krusenstjernas författarskap. Redan ett drygt decennium efter författarens död kom Olof Lagercrantz biografiska studie Agnes von Krusenstjerna (195I). Därefter dröjde det närmare fyrtio år innan Birgitta Svanbergs Sanningen om kvinnorna: En läsning av Agnes von Krusenstjernas romanserie Fröknarna von Pablen (1989) förde in hennes mest kända svit i en psykoanalytisk och feministisk tolkningsram och uppmärksammade dess antifascistiska hållning som en samtidspolitisk protest. Den på sin tid kontroversiella romansviten blev också huvudnumret i Rita Paqvaléns Kampen om Eros: Om kön och kärlek i Pablen- 
sviten (2007) som öppnade den mot queerteoretiska och intersektionella perspektiv. Som all forskning är dessa studier barn av sin tid och bidrar med värdefull kunskap om författarskapet, tiden och forskningens tolkningshorisont. Överhuvudtaget har Krusenstjernas verk på senare tid fått mer uppmärksamhet än många andra i hennes generation genom en rad studier om utvecklingstemat, flickboken, modernismen och den lesbiska kärleken.

Med sin avhandling om kvinnoblivandet för Jakobsson forskningen framåt och det är glädjande att hon ägnar sin bok åt de undanskymda tidiga romanerna, debuten Ninas dagbok (I9I7) och uppföljaren Helenas första kärlek: En Stockholmsroman (I918), som ofta blivit sedda lite över axeln som flickböcker i författarskapets startgropar. Jakobsson ställer sig klokt avog till den kritik som avfärdat dem på grund av flickboksassociationerna och visar att de innehåller spännande ledtrådar till den svenska mellankrigstidens kanske mest omstridda författarskap. Dessutom lyfter hon upp den första lysande sviten Tony växer upp, Tonys läroår och Tonys sista läroår som blev det litterära genombrottet. Avhandlingens utredning av hur begreppet flicka används i romanerna borde för övrigt kunna ligga till grund för fortsatta komparativa analyser inom litteraturforskningen om barndom och uppväxt.

Jakobsson undersöker vad den heterosexuella "kvinnotillblivelse" som genomsyrar Krusenstjernas romankonst egentligen innebär (lesbisk kärlek i författarskapet har tidigare behandlats av Rita Paqvalén 2007, Liv Saga Bergdahl 2010, Jenny Björklund 2014 och Eva Borgström 20I6). Ämnet är välvalt: från debuten I9I7 fram till den sista sviten "Fattigadel” (I935-I938) återkommer Krusenstjerna om och om igen till flickans utveckling och mognad till kvinna genom sexualiteten, kroppen och kärleken. För att utreda skeendet narrativt och tematiskt använder Jakobsson begreppen skev och queer och belyser romanernas livsskildringar med inspiration från Jack Halberstams teorier kring "life schedules" och Sara Ahmeds kring "lifeline". Livslinjen är "en temporaliserad berättelse om ett livsförlopp som förhåller sig till förväntningar om olika faser som barndom, uppväxt, vuxenhet och ålderdom och som inkluderar ett nu, en dåtid och en framtid” (Jakobsson 2018, 29). 
Enligt Jakobsson presenterar texterna skilda lösningar på hur flickan ska erövra den frihet hon längtar efter. En förutsättning är att hon finner den ideale älskaren - gör hon inte det blir hon heller inte kvinna och vuxet subjekt. Avhandlingen visar att de två första romanerna följer en krononormativ linje som slutar med att flickan blir kvinna genom sitt val av älskare/make med det heterosexuella äktenskapet som ideal. Protagonisten i Tonysviten däremot tecknar en "skev" livslinje som kontrasterar mot den traditionella flickbokens matris. Slutsatserna kring Tonysviten tillhör det mest intressanta i avhandlingen och fångar något väsentligt i Krusenstjernas gränsöverskridande idévärld. Tony väljer män som hindrar henne från att mogna till kvinna. Det genreförväntade lyckliga slutet uteblir vilket enligt Jakobsson är "i linje med verkets logik" ( $\mathrm{f} 76$ ). I en fin analys iakttar hon romanens gestaltning av tomhet och det som aldrig blir av som en nyckel till den uteblivna vuxenheten, komprimerat i svitens vackra och omskrivna slutmening: "Då grät jag, därför att jag inte hade något fäste." (Krusenstjerna 1926, 322)

Att därmed, som Jakobsson hävdar, själva flickboken "skevas" ställer jag mig skeptisk till. Tolkningen är avhängig hur sviten genreplaceras; Jakobsson påpekar att varken hon, forskningen eller kritiken definierat den som flickbok, men hon vill ändå argumentera för en skevande påverkan eftersom intrigen är densamma som i de traditionella flickböckerna.

Med hjälp av livslinjerastret frilägger Jakobsson inte bara de krusenstjernska "avvikelserna" utan också deras subversiva potential som alternativa eller oppositionella livslinjer i ett samhälle som upprättar bestämda villkor kring kärlek, samlevnad och äktenskap. Processen handlar också om de restriktioner som styr kvinnotillblivelsen och Jakobsson övertygar med sin slutsats att romanerna kan inordnas i en tradition där en funktion hos det litterära projektet var att ur ett kritiskt-feministiskt perspektiv granska unga kvinnors sociala villkor.

En förtjänst är att textanalyserna ackompanjeras av komparativa inslag som vidgar horisonten och etablerar intertextuella förbindelser som inte synliggjorts lika ingående i tidigare forskning. Romanerna diskuteras utifrån deras släktskap med den angloamerikanska litteraturen 
med nedslag hos Frances Hodgson Burnett, Jean Webster och Lucy M. Montgomery. I en iakttagelse som märkligt nog kommer först i avhandlingens slutord pekar Jakobsson på den intrikata relationen till två klassiska verk som explicit nämns i Tonysviten, nämligen Lewis Carrolls Alice's Adventures in Wonderland och J. M. Barries Peter and Wendy. Liksom Alice brottas Tony med en kropp i förvandling och liksom Peter Pan blir hon aldrig riktigt vuxen inom berättelsens ramar.

Däremot är avhandlingen märkbart tyst kring idédebatterna om samhälle, kön och sexualitet i romanernas tillkomsttid då inflytelserika aktörer som Ellen Key och Elin Wägner uppenbart satte avtryck hos författaren. En annan brist är att klass, som är fundamentalt hos Krusenstjerna, tillmäts långt mindre betydelse än kön och ålder. Även de tidiga romanerna är laddade med markörer som signalerar adelns eller borgerlighetens avstånd till arbetarklassen. Klass skrivs ju också fram som ett hinder i flickans kvinnoblivande genom fokus på konventionernas och traditionernas hårda tyglar som får bidra till att förklara Tonys strandade relationer. I klassens ögon gör hon en "skev" livslinje. Det ges ingen fördjupning i studien.

Jakobssons styrka ligger i den uppmärksamma blicken på texterna. Som läsare är hon lyhörd och grundlig och med sin avhandling tillför hon ny kunskap om Krusenstjernas litterära karta och intertextuella rum. Hon ger besked om att romanerna tål att läsas på nytt.

ANNA WILLIAMS UPPSALA UNIVERSITET

\section{REFERENSER}

Bergdahl, Liv Saga. 2o oo. "Kärleken utan namn: Identitet och (o)synlighet i svenska lesbiska romaner." Avhandling, Umeå universitet.

Björklund, Jenny. 2014. Lesbianism in Swedish Literature: An Ambiguous Affair. Basingstoke: Palgrave Macmillan.

Borgström, Eva. 20I6. Berättelser om det förbjudna: Begär mellan kvinnor i svensk litteratur 1900-1935. Göteborg: Makadam. 
Krusenstjerna, Agnes von. 1924. Tonys läroår: Episoder ur en ungdom. Stockholm: Bonnier.

-. 1926. Tonys sista läroår: Resa till Kejsarens hotell. Stockholm: Bonnier.

Lagercrantz, Olof. 195 I. Agnes von Krusenstjerna. Stockholm: Bonnier.

Paqvalén, Rita. 2007. "Kampen om Eros: Om kön och kärlek i Pahlensviten.” Avhandling, Helsingfors universitet.

Svanberg, Birgitta. 1989. Sanningen om kvinnorna: En läsning av Agnes von Krusenstjernas romanserie Fröknarna von Pablen. Stockholm: Gidlund. 